\title{
Serum uric acid as a predictor of cardio- and cerebro-vascular diseases in maintenance hemodialysis patients
}

\author{
NAJMEH KHODABANDEH ${ }^{1}$, ELAHE TAZIKI $^{2}$, TOKTAM ALIREZAEI $^{3 *}$
}

\author{
${ }^{1}$ Resident of Internal Medicine, Clinical Research Development Unit of Shohada Tajrish Hospital, Shahid Beheshti \\ University of Medical Science, Tehran, Iran \\ ${ }^{2}$ Associated professor of nephrology. Shohada Tajrish Hospital, Shahid Beheshti University of \\ Medical Science, Tehran Iran \\ ${ }^{3}$ Associated professor of cardiology. Clinical Research Development Unit of Shohada Tajrish Hospital, Shahid Beheshti \\ University of Medical Science, Tehran, Iran
}

\begin{abstract}
Background: Hyperuricemia is associated with an increased risk of cardio-and cerebrovascular disease (CVD) in general population. However, in the hemodialysis (HD) patients, low serum uric acid (SUA) increases the risk of mortality. Considering that CVD is the principal cause of death among maintenance HD patients, the present study aimed to determine the predictive value of SUA for CVD outcome in this population.

Methods: In this two-year follow-up prospective study, 205 outpatients under maintenance HD were enrolled from March 2017 to 2020. Patients' demographic data, underlying diseases, and the results of serum tests, as well as two-year follow-up results of CVD events and mortality were recorded.

Results: A total of 130 (63\%) patients were eligible for analysis; $62.9 \%$ were male; mean age of participants was $59 \pm 13$ years. At follow-up, coronary artery disease was observed in $43.2 \%$, peripheral artery disease in $26.5 \%$, and cerebrovascular disease in $20.5 \%$; angiography was required in $52.3 \%$ and $4.5 \%$ died of CVD. SUA was $\leq 5.4 \mathrm{mg} / \mathrm{dL}$ in 52 patients, $5.5-6.1 \mathrm{mg} / \mathrm{dL}$ in 19 , and $\geq 6.2 \mathrm{mg} / \mathrm{dL}$ in 59 patients with significant difference based on mean age, sex distribution, occurrence of cerebrovascular disease and cardiovascular mortality $(\mathrm{P}<0.05)$. Patients with cerebrovascular disease had a significantly lower SUA levels $(\mathrm{P}=0.006)$. Logistic regression showed the significant effect of SUA on the occurrence of cerebrovascular disease $(\mathrm{P}=0.008)$.

Conclusion: Low SUA can predict two-year incidence of cerebrovascular disease in HD patients. However, SUA levels did not show significant predictive effect on two-year coronary events, peripheral artery disease and cardiovascular mortality.
\end{abstract}

Key words: cerebrovascular disorders, heart diseases, peripheral arterial disease, renal dialysis, uric acid.

\section{What is new? What is important?}

- High serum uric acid (SUA) is associated with an increased risk of mortality in general population, studies in hemodialysis (HD) patients are conflicting.

- Low SUA reflects poor nutritional status in HD patients and is associated with increased risk of mortality.

- Cardio-and cerebro-vascular disease is the principal cause of death among HD patients.

- Low SUA can predict two-year incidence of cerebrovascular disease in HD patients.

- SUA levels did not show significant predictive effect on two-year coronary events, peripheral artery disease and cardiovascular mortality.

\section{INTRODUCTION}

Chronic kidney disease (CKD) is a major health issue in the world that can result in end stage renal disease (ESRD) and increased risk of mortality and morbidity [1]. Patients with ESRD require renal replacement therapy (RRT), including peritoneal dialysis, kidney transplantation, and hemodialysis (HD) [2,3]; but the overall survival of the most common RRT, the HD, is approximately eight years. In Iran, less than 5\% of HD patients have $\geq 10$-year survival $[4,5]$.

One of the major reasons for the limited survival of HD patients is its contribution with noncommunicable diseases, such as hypertension (HTN), diabetes mellitus (DM), hyperlipidemia, and CVD, which increase patients' morbidity and mortality $[6,7]$. In addition to comorbidities, several 
serum parameters have been associated with increased risk of mortality in HD patients, including low serum levels of hemoglobin and high-density lipoprotein cholesterol [8].

Hyperuricemia is associated with metabolic syndrome and considered an important predictor of development of CVD in patients with DM [9]. In HD patients, studies have shown higher rate of allcause mortality in patients with hyperuricemia that suggest the reverse relationship between SUA and survival, although such association has not been confirmed between SUA and CVD mortality [10, 11]. Others have also suggested that higher SUA in HD patients, within a specific range $(>8 \mathrm{mg} / \mathrm{dl})$, is associated with better nutritional status and lower all-cause mortality, especially in those with low protein intake [12]. Therefore, SUA is recommended as a useful nutritional predictor of HD outcome [13]. However, its diagnostic accuracy for development of CVD in HD patients is unclear.

As CVD is considered the first cause of death and the most common comorbidity in HD patients [6], studying the predictors of CVD in HD patients can help prevent or delay its occurrence by earlier diagnosis/treatment and thus improve patients' survival [14]. Considering the significance of CVD in patients undergoing $\mathrm{HD}$, this study aimed to determine the predictive value of SUA for development of CVD during a two-year follow-up in HD patients without baseline cardiac disease.

\section{MATERIALS AND METHODS}

\section{Study design}

Adult patients who underwent HD at Shohadae-Tajrish Hospital, Tehran, Iran, March 2017-2020, were considered as the study population of the present observational prospective study. The protocol of the study was approved by the Ethics Committee of Shahid Beheshti University of Medical Sciences (code: IR.SBMU.RETECH.REC.1397.1037). The study objectives were explained to the participants and they were asked to read and sign the written informed consent form.

Inclusion criteria were ESRD outpatients who underwent maintenance $\mathrm{HD}$ for at least three months, aged $>18$ years, without history of CVD, with an anticipated life expectancy of $>6$ months, without amputations or any other body deformities, without history of comorbidities (such as autoimmune disease, infectious diseases, neoplasms or chemotherapy), and did not use medications that affected UA levels (e.g., prednisone, allopurinol).

An internal medicine physician examined the patients and recorded their demographics, such as age and sex, anthropometric variables, such as height, weight, smoking status, and their past medical history, including underlying diseases (renal diseases, DM, HTN, etc.) in the study checklist. One fasting venous blood sample was taken from all participants (preferably from the cubital vein) before hemodialysis, collected in heparinated tubes, and sent to the Hospital's laboratory immediately. SUA was measured by peroxidase method that measures SUA up to $18 \mathrm{mg} / \mathrm{dL}$ with a normal range of $3.6-8.2 \mathrm{mg} / \mathrm{dL}$ in men and $2.3-6.1 \mathrm{mg} / \mathrm{dL}$ in women. Patients with a baseline SUA level of $<12 \mathrm{mg} / \mathrm{dL}$ were included into the study and patients with SUA level of $\geq 12 \mathrm{mg} / \mathrm{dL}$ were referred to the specialist for treatment of hyperuricemia and excluded from the study [15]. All of the serum parameters, including serum creatinine, blood urea nitrogen (BUN), calcium, phosphorus, bicarbonate, and serum lipids were measured by automatic analyzers.

Transthoracic echocardiography was done for all patients to assess the contractility, presence of regional wall motion abnormality and valvular function. Patients with significant abnormality in echocardiography (e.g. ejection fraction $<50 \%$ or significant valvular disease) were excluded and referred to the specialist for further care and treatment.

Patients without any significant abnormality in the baseline electrocardiogram were followed for two years and the occurrence of cardiac events (acute myocardial infarction and unstable angina), peripheral artery disease, cerebrovascular disease, angiography procedures (like coronary artery angiography), and CVD mortality were recorded at two-year follow-up visit. Peripheral artery diseases were defined as aorto-iliac, femoropopliteal, or carotid disease. Diagnosis of stroke was made by the neurologist on the basis of clinical and brain imaging findings. Patients who underwent renal transplantation during the study period, were transferred to another center, used any medication that affected SUA, or refused to continue the study were excluded from the study.

\section{Statistical analysis}

All analyses were performed using $\mathrm{R}$ (version: 4.1.2) and SPSS (version: 25). For describing the results of continuous variables, 
mean \pm standard deviation (SD) was used and for the nominative variables, frequency (percentage). SUA levels were categorized into three levels, based on a similar study and the variables were compared with the categories, as well as mean SUA levels for more accurate results [16]. One-sample KolmogorovSmirnov test was used to determine the normal distribution of data and Levene's test was used to test the equality of variances. Comparison of these variables among the groups was performed using independent samples $t$ test or one way ANOVA, based on the number of groups. Categorical variables were compared using chi-square test. The effect of serum uric acid on the occurrence of cardio-and cerebro-vascular events was estimated through ordinary logistic regression models. Due to the low number of events relative to the number of regression coefficients estimated, Firth's logistic regression was used for predicting acute myocardial infarction, unstable angina, peripheral artery disease and cerebrovascular disease. Firth's correction is as a useful approach for reducing the small sample bias of maximum likelihood estimation [17]. All logistic regression analysis models were adjusted for variables (baseline characteristics and underlying disease) in univariate analysis with $p<0.05$. The Firth's method was implemented using the R package "logistf" [18].

\section{RESULTS}

A total of 130 patients completed the study. The baseline characteristics of the study population (demographic and clinical characteristics) are shown in Table 1. As shown, the majority were male $(62.9 \%)$ and the mean age of participants was $59 \pm 13$ years. At follow-up, a total of 57 patients (43.8\%) had coronary artery events (38 had unstable angina and 19 AMI), 69 patients (53.0\%) underwent angiographic study, 35 patients $(26.9 \%)$ had peripheral artery disease, and $27(20.7 \%)$ had cerebrovascular disease; a total of 6 patients $(4.5 \%)$ died of CVD. The frequency of the cardiac events was not different between male and female patients $(\mathrm{P}>0.05$; data not shown). The distribution of SUA among the study population was normal.

Table 1

The baseline characteristics of the study population categorized based on serum level of uric acid

\begin{tabular}{|c|c|c|c|c|c|c|}
\hline & & $\begin{array}{l}\text { Total } \\
(\mathbf{N}=130)\end{array}$ & $\begin{array}{l}\text { Group } 1 \\
(\text { SUA } \leq 5.4 \\
(\mathrm{N}=52)\end{array}$ & $\begin{array}{l}\text { Group } 2 \\
\text { (SUA: } 5.5- \\
6.1)(N=19)\end{array}$ & $\begin{array}{l}\text { Group } 3 \\
\text { (SUA } \\
\geq 6.2) \\
(\mathrm{N}=59)\end{array}$ & p-value \\
\hline \multirow{8}{*}{$\begin{array}{l}\text { Baseline } \\
\text { characteristics }\end{array}$} & Age (years), mean \pm SD & $59 \pm 13$ & $59 \pm 14$ & $66 \pm 13$ & $57 \pm 13$ & $0.040^{*}$ \\
\hline & Female sex $(\%)$ & $37.7 \%$ & $50.0 \%$ & $42.1 \%$ & $25.4 \%$ & $0.027^{\dagger *}$ \\
\hline & Weight $(\mathrm{kg})$, mean \pm SD & $69 \pm 13$ & $66 \pm 11$ & $65 \pm 9$ & $73 \pm 14$ & $0.006^{* *}$ \\
\hline & Height, mean \pm SD & $166 \pm 8$ & $165 \pm 7$ & $164 \pm 6$ & $167 \pm 8$ & $0.117^{*}$ \\
\hline & Body mass index, mean \pm SD & $25 \pm 4$ & $24 \pm 4$ & $24 \pm 3$ & $26 \pm 5$ & $0.090^{*}$ \\
\hline & $\begin{array}{l}\begin{array}{l}\text { Systolic blood } \\
(\mathrm{mmHg}),\end{array} \text { mean } \pm \text { SD }\end{array}$ & $122 \pm 15$ & $123 \pm 15$ & $117 \pm 14$ & $123 \pm 14$ & $0.312^{*}$ \\
\hline & $\begin{array}{l}\text { Duration of dialysis (month), } \\
\text { mean } \pm \text { SD }\end{array}$ & $27 \pm 30$ & $24 \pm 22$ & $26 \pm 19$ & $30 \pm 38$ & $0.593^{*}$ \\
\hline & Smoking (\%) & $23.1 \%$ & $15.4 \%$ & $36.8 \%$ & $25.4 \%$ & $0.143^{\dagger}$ \\
\hline \multirow{9}{*}{$\begin{array}{l}\text { Underlying } \\
\text { disease }\end{array}$} & Hypertension (\%) & $50.8 \%$ & $50.00 \%$ & $47.4 \%$ & $52.5 \%$ & $0.915^{\dagger}$ \\
\hline & Diabetes mellitus (\%) & $46.2 \%$ & $50.00 \%$ & $42.1 \%$ & $44.1 \%$ & $0.789^{\dagger}$ \\
\hline & Dyslipidemia (\%) & $6.9 \%$ & $9.6 \%$ & $5.3 \%$ & $5.1 \%$ & $0.720^{\dagger}$ \\
\hline & Myocardial infarction (\%) & $14.6 \%$ & $15.4 \%$ & $21.1 \%$ & $11.9 \%$ & $0.602^{\dagger}$ \\
\hline & Unstable angina $(\%)$ & $29.2 \%$ & $26.9 \%$ & $15.8 \%$ & $35.6 \%$ & $0.229^{\dagger}$ \\
\hline & Angiography (\%) & $53.0 \%$ & $53.1 \%$ & $50.00 \%$ & $54.2 \%$ & $0.951^{\dagger}$ \\
\hline & $\begin{array}{l}\text { Peripheral vascular disease } \\
(\%)\end{array}$ & $26.9 \%$ & $27.1 \%$ & $41.2 \%$ & $25.4 \%$ & $0.439^{\dagger}$ \\
\hline & Cerebrovascular disease $(\%)$ & $20.7 \%$ & $30.6 \%$ & $41.2 \%$ & $8.5 \%$ & $0.002^{\dagger}$ \\
\hline & Cardiovascular mortality & $4.6 \%$ & $3.8 \%$ & $15.8 \%$ & $1.7 \%$ & $0.037^{\dagger}$ \\
\hline
\end{tabular}

*the results of one way anova, ${ }^{\dagger}$ the results of chi square test; significance level was $<0.05$; ${ }^{\dagger}$ the results of posthoc test showed that age was significantly different between groups 2 and $3(\mathrm{p}=0.031)$, but not between other groups and weight was different between groups 1 and $3(\mathrm{p}=0.012)$ and between groups 2 and $3(\mathrm{p}=0.046)$. 
Categorizing patients based on SUA showed that $\mathrm{SUA} \leq 5.4 \mathrm{mg} / \mathrm{dL}$ in 52 patients, SUA of $5.5-6.1 \mathrm{mg} / \mathrm{dL}$ in 19 patients, and SUA $\geq 6.2 \mathrm{mg} / \mathrm{dL}$ in 59 patients; comparing the study variables based on these categories showed significant difference among the three groups in terms of mean age, sex distribution, occurrence of cerebrovascular disease and cardiovascular mortality $(\mathrm{P}<0.05$; Table 1$)$, but the rest of the variables were not significantly different among patients with three categories of SUA $(\mathrm{P}>0.05$; Table 1). Studying the mean SUA also showed a significantly higher mean value of SUA in male patients, compared to female patients $(6.22 \pm 1.42$ vs. $5.69 \pm 1.35 ; \mathrm{P}=0.039)$.

Mean levels of the serum parameters compared between the patients with and without CVD at two-year follow-up are shown in Table 2.
As demonstrated, patients with cerebrovascular disease had a significantly lower SUA levels $(\mathrm{P}=0.006)$ and patients with peripheral artery disease had a lower phosphorus level $(\mathrm{P}=0.048)$ and lower creatinine level $(\mathrm{P}=0.015)$, while the rest of serum parameters were not different between patients with or without different types of CVD (P>0.05; Table 2).

The logistic regression, adjusted for weight and age and gender, in predicting the occurrence of cerebrovascular disease showed significant effect of $S U A \geq 6.2(p=0.029)$. Compared to the reference group (i.e. 5.5-6.1), SUA level equal to or greater than 6.2 was associated with decreased odds of cerebrovascular disease $(\mathrm{OR}=0.218,95 \%$ CI, $0.053-0.854, \mathrm{p}=0.029$ ). The odds of other diseases were not associated with SUA level (p>0.05) (Table 3).

Table 2

Comparison of mean levels of serum parameters based on the two-year follow-up cardiovascular outcome of the patients

\begin{tabular}{|c|c|c|c|c|c|c|c|c|c|c|c|c|}
\hline$\frac{\frac{0}{2}}{\frac{\pi}{3}}$ & 莺 & 䒕 & 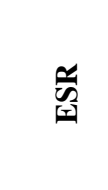 & 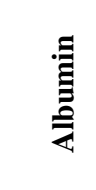 & & $\underset{D}{Z}$ & 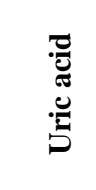 & 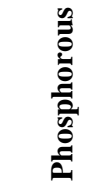 & 音 & 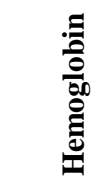 & 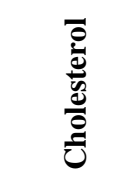 & 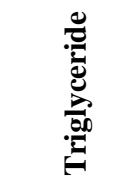 \\
\hline हैं & & $\begin{array}{l}17.36 \pm \\
23.44\end{array}$ & $\begin{array}{l}19.30 \pm \\
12.86\end{array}$ & $\begin{array}{l}3.88 \pm \\
0.50\end{array}$ & $\begin{array}{l}7.41 \pm \\
2.77\end{array}$ & $\begin{array}{l}96.79 \pm \\
37.64\end{array}$ & $\begin{array}{l}6.02 \pm \\
1.42\end{array}$ & $\begin{array}{l}5.85 \pm \\
1.29\end{array}$ & $\begin{array}{l}8.54 \pm \\
0.95\end{array}$ & $\begin{array}{l}10.56 \pm \\
1.79\end{array}$ & $\begin{array}{l}120.46 \pm \\
33.45\end{array}$ & $\begin{array}{l}121.41 \pm \\
61.68\end{array}$ \\
\hline \multirow{3}{*}{ 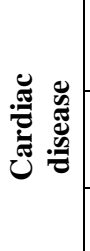 } & Yes & $\begin{array}{l}16.38 \pm \\
22.58\end{array}$ & $\begin{array}{l}20.94 \pm \\
15.05\end{array}$ & $\begin{array}{l}3.87 \pm \\
0.51\end{array}$ & $\begin{array}{l}7.58 \pm \\
2.88\end{array}$ & $\begin{array}{l}100.66 \pm \\
39.48\end{array}$ & $\begin{array}{l}6.14 \pm \\
1.53\end{array}$ & $\begin{array}{l}5.80 \pm \\
1.35\end{array}$ & $\begin{array}{l}8.60 \pm \\
0.91\end{array}$ & $\begin{array}{l}10.75 \pm \\
1.79\end{array}$ & $\begin{array}{l}120.47 \pm \\
34.07\end{array}$ & $\begin{array}{l}118.47 \pm \\
54.77\end{array}$ \\
\hline & No & $\begin{array}{l}18.23 \pm \\
26.22\end{array}$ & $\begin{array}{l}18.02 \pm \\
10.78\end{array}$ & $\begin{array}{l}3.88 \pm \\
0.49\end{array}$ & $\begin{array}{l}7.27 \pm \\
2.70\end{array}$ & $\begin{array}{l}93.85 \pm \\
36.16\end{array}$ & $\begin{array}{l}5.92 \pm \\
1.32\end{array}$ & $\begin{array}{l}5.90 \pm \\
1.26\end{array}$ & $\begin{array}{l}8.50 \pm \\
0.98\end{array}$ & $\begin{array}{l}10.40 \pm \\
1.79\end{array}$ & $\begin{array}{l}120.46 \pm \\
33.20\end{array}$ & $\begin{array}{l}123.65 \pm \\
66.73\end{array}$ \\
\hline & P-value* & 0.714 & 0.200 & 0.914 & 0.532 & 0.305 & 0.381 & 0.667 & 0.578 & 0.285 & 0.999 & 0.635 \\
\hline \multirow{3}{*}{ 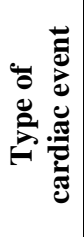 } & AMI & $\begin{array}{l}18.52 \pm \\
26.22\end{array}$ & $\begin{array}{l}19.84 \pm \\
16.23\end{array}$ & $\begin{array}{l}3.83 \pm \\
0.52\end{array}$ & $\begin{array}{l}6.55 \pm \\
2.48\end{array}$ & $\begin{array}{l}106.55 \pm \\
37.39\end{array}$ & $\begin{array}{l}6.33 \pm \\
1.55\end{array}$ & $\begin{array}{l}5.68 \pm \\
1.35\end{array}$ & $\begin{array}{l}8.48 \pm \\
0.86\end{array}$ & $\begin{array}{l}10.99 \pm \\
1.81\end{array}$ & $\begin{array}{l}121.92 \pm \\
30.08\end{array}$ & $\begin{array}{l}123.07 \pm \\
58.18\end{array}$ \\
\hline & $\begin{array}{l}\text { Unstable } \\
\text { angina }\end{array}$ & $\begin{array}{l}11.76 \pm \\
10.94\end{array}$ & $\begin{array}{l}23.15 \pm \\
12.47\end{array}$ & $\begin{array}{l}3.96 \pm \\
0.51\end{array}$ & $\begin{array}{l}6.55 \pm \\
2.48\end{array}$ & $\begin{array}{l}88.89 \pm \\
41.90\end{array}$ & $\begin{array}{l}5.75 \pm \\
1.45\end{array}$ & $\begin{array}{l}6.02 \pm \\
1.34\end{array}$ & $\begin{array}{l}8.82 \pm \\
1.02\end{array}$ & $\begin{array}{l}10.26 \pm \\
1.67\end{array}$ & $\begin{array}{l}117.57 \pm \\
41.70\end{array}$ & $\begin{array}{l}109.26 \pm \\
47.34\end{array}$ \\
\hline & p-value ${ }^{*}$ & 0.252 & 0.438 & 0.368 & 0.445 & 0.112 & 0.181 & 0.379 & 0.190 & 0.152 & 0.654 & 0.374 \\
\hline \multirow{3}{*}{ 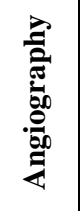 } & Yes & $\begin{array}{l}17.20 \pm \\
24.33\end{array}$ & $\begin{array}{l}19.31 \pm \\
14.21\end{array}$ & $\begin{array}{l}3.85 \pm \\
0.46\end{array}$ & $\begin{array}{l}7.43 \pm \\
2.91\end{array}$ & $\begin{array}{l}100.13 \pm \\
38.40\end{array}$ & $\begin{array}{l}6.05 \pm \\
1.58\end{array}$ & $\begin{array}{l}5.65 \pm \\
1.40\end{array}$ & $\begin{array}{l}8.62 \pm \\
1.02\end{array}$ & $\begin{array}{l}10.57 \pm \\
1.65\end{array}$ & $\begin{array}{l}115.78 \pm \\
31.04\end{array}$ & $\begin{array}{l}119.98 \pm \\
52.87\end{array}$ \\
\hline & No & $\begin{array}{l}17.69 \pm \\
23.06 \\
\end{array}$ & $\begin{array}{l}19.25 \pm \\
11.66 \\
\end{array}$ & $\begin{array}{l}3.93 \pm \\
0.55 \\
\end{array}$ & $\begin{array}{l}7.39 \pm \\
2.65 \\
\end{array}$ & $\begin{array}{l}92.96 \pm \\
37.07 \\
\end{array}$ & $\begin{array}{l}6.05 \pm \\
1.23 \\
\end{array}$ & $\begin{array}{l}6.01 \pm \\
1.14 \\
\end{array}$ & $\begin{array}{l}8.45 \pm \\
0.84 \\
\end{array}$ & $\begin{array}{l}10.52 \pm \\
2.01 \\
\end{array}$ & $\begin{array}{l}126.61 \pm \\
35.64 \\
\end{array}$ & $\begin{array}{l}118.76 \pm \\
68.71 \\
\end{array}$ \\
\hline & P-value* & 0.923 & 0.983 & 0.387 & 0.943 & 0.287 & 0.983 & 0.118 & 0.294 & 0.882 & 0.072 & 0.910 \\
\hline \multirow{3}{*}{ 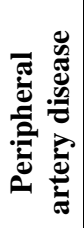 } & Yes & $\begin{array}{l}14.66 \pm \\
23.88 \\
\end{array}$ & $\begin{array}{l}19.85 \pm \\
18.73 \\
\end{array}$ & $\begin{array}{l}3.88 \pm \\
0.49 \\
\end{array}$ & $\begin{array}{l}6.41 \pm \\
2.24 \\
\end{array}$ & $\begin{array}{l}99.42 \pm \\
36.59 \\
\end{array}$ & $\begin{array}{l}5.98 \pm \\
1.61 \\
\end{array}$ & $\begin{array}{l}5.47 \pm \\
1.46 \\
\end{array}$ & $\begin{array}{l}8.60 \pm \\
0.99 \\
\end{array}$ & $\begin{array}{l}10.69 \pm \\
1.77 \\
\end{array}$ & $\begin{array}{l}114.48 \pm \\
24.23 \\
\end{array}$ & $\begin{array}{l}125.68 \pm \\
61.12 \\
\end{array}$ \\
\hline & No & $\begin{array}{l}17.91 \pm \\
22.27 \\
\end{array}$ & $\begin{array}{l}18.76 \pm \\
9.51 \\
\end{array}$ & $\begin{array}{l}3.88 \pm \\
0.514 \\
\end{array}$ & \begin{tabular}{|l|}
$7.77 \pm$ \\
2.94 \\
\end{tabular} & $\begin{array}{l}96.81 \pm \\
38.64 \\
\end{array}$ & $\begin{array}{l}6.11 \pm \\
1.35 \\
\end{array}$ & $\begin{array}{l}5.99 \pm \\
1.21 \\
\end{array}$ & $\begin{array}{l}8.57 \pm \\
0.93 \\
\end{array}$ & $\begin{array}{l}10.54 \pm \\
1.78 \\
\end{array}$ & $\begin{array}{l}121.60 \pm \\
35.53 \\
\end{array}$ & $\begin{array}{l}119.41 \pm \\
61.98 \\
\end{array}$ \\
\hline & P-value ${ }^{*}$ & 0.552 & 0.744 & 0.996 & 0.015 & 0.731 & 0.670 & 0.048 & 0.888 & 0.663 & 0.202 & 0.611 \\
\hline
\end{tabular}




\begin{tabular}{|l|l|l|l|l|l|l|l|l|l|l|l|l|} 
(Table 2 continued) \\
\hline
\end{tabular}

*the results of independent samples $\mathrm{t}$ test; significance level was $<0.05$ abbreviations: crp - creactive protein, esr - estimated sedimentation ration, bun - blood urea nitrogen.

Table 3

Association between each cardiovascular outcome and the serum uric acid levels

\begin{tabular}{llcll}
\hline & \multicolumn{2}{c}{ SUA $\leq \mathbf{5 . 4}$ (reference=5.5-6.1) } & \multicolumn{2}{l}{$\begin{array}{l}\text { SUA } \geq \mathbf{6 . 2} \\
\text { (reference=5.5-6.1) }\end{array}$} \\
\hline Cardiac event & OR(95\%CI) & P-value & OR(95\%CI) & P-value \\
\hline Myocardial infarction & $1.338(0.437,4.096)$ & 0.610 & $1.536(0.496,4.755)$ & 0.457 \\
\hline Unstable angina & $0.706(0.196,2.800)$ & 0.604 & $0.528(0.136,2.223)$ & 0.369 \\
\hline Angiography & $1.812(0.514,7.944)$ & 0.368 & $2.509(0.720,11.012)$ & 0.154 \\
\hline Peripheral artery disease & $1.539(0.483,4.905)$ & 0.466 & $1.586(0.489,5.145)$ & 0.442 \\
\hline Cerebrovascular disease & $0.687(0.211,2.297)$ & 0.536 & $0.655(0.199,2.260)$ & 0.494 \\
\hline
\end{tabular}

Note: Models were adjusted for weight and age and gender.

Statistical analysis was performed by ordinary logistic regression or Firth's logistic regression, as appropriate.

\section{DISCUSSION}

The present study investigated the predictive ability of SUA and other serum parameters with two-year incidence of CVD and cardiovascular mortality. The results showed that mean SUA could not predict two-year cardiovascular mortality. However, categorizing the SUA to three levels $(\leq 5.4,5.5-6.1$, and $\geq 6.2$ $\mathrm{mg} / \mathrm{dL}$ ) showed that patients with SUA level of $5.5-6.1 \mathrm{mg} / \mathrm{dl}$ had a significantly higher cardiovascular mortality after two years (15.8\%), compared to the two other groups. These tertile have been previously used by Beberashvili and colleagues and they have shown that CVD deaths were significantly different among the three groups [16], which is similar to the results of the presents study; although the obtained statistics (about the mortality rate) were dissimilar. They also reported that each unit increase in SUA reduced the cardiovascular mortality at 0.6 [16]. Considering the association of SUA with cardiovascular mortality, the results of previous studies are controversial. Kim et al. have reported that SUA is not associated with cardiovascular mortality, although it is significantly associated with all-cause mortality in 7,333 Korean HD patients (mean age of $61 \pm 14$ years; $61 \%$ male) [11], while Latif et al. have reported significant hazard ratio (HR) of 0.9 for SUA levels for both all-cause and cardiovascular mortality and HR of 1.03 and 1.54 , respectively, for SUA levels $\leq 8.2 \mathrm{mg} / \mathrm{dl}$ vs. $>8.2 \mathrm{mg} / \mathrm{dl}$ in $5,827 \mathrm{HD}$ patients from five countries, which suggest SUA is a cardioprotective agent, possibly related to the antioxidant properties of uric acid [10]. Others have also suggested that SUA in HD patients, within a specific range $(<8 \mathrm{mg} / \mathrm{dl})$, is associated with lower all-cause mortality [12)]. The discrepancy in the results of studies could be due to the differences in the study design and inclusion criteria of the patients. we have excluded any patient who used uric acid lowering agents, such as allopurinol, in order to study the pure effect of SUA on cardiovascular mortality, while Latif et al. have not excluded these patients. Furthermore, due to the ethical issues, we referred any patient who was diagnosed with hyperuricemia for treatment and included only patients with SUA level 
$<12 \mathrm{mg} / \mathrm{dl}$. Besides, the mortality of HD patients varies based on patients' demographics, such as race, age, and sex [19], as well as HD parameters, like delivered dialysis dose and frequency [20]; and the variability of these characteristics are another cause for the difference in the results of the studies.

Considering the association of other serum parameters, including inflammatory (C-reactive protein [CRP] and estimated sedimentation ratio [ESR]), and nutritional (albumin, creatinine, and blood urea nitrogen [BUN], cholesterol, triglyceride (TG), phosphorous, calcium, and hemoglobin [Hb]) parameters with cardiovascular mortality, the results of the present study showed no association in this regard. These results reject the effect of these serum parameters on twoyear cardiovascular mortality in HD patients. The results of other studies have also rejected association of $\mathrm{Hb}$ with mortality in HD patients $[21,22]$, which is similar to the results of the present study. But, literature review of studies reveals inconsistency in the results in this regard, as well. In a review of studies, Krediet and Balafa also reported no evidence of the association of serum lipid profile with cardiovascular mortality in HD patients [23], which confirms the results of the present study. This is while Chang et al. have reported protective effects of $\mathrm{TG}$ for cardiovascular mortality in HD patients [24], which confirm the causal relationship between lipid profile and $\mathrm{CV}$ death in this population. However, these results are inconsistent with that of the present study, which could be due to the use of lipidlowering agents by the patients in our study and exclusion of patients with ischemic heart disease at the beginning of the study. Therefore, dyslipidemia, frequently observed in HD patients [25, 26], was not found in our patients. Also, the changed renal status can be another factor for fluctuation of lipid profile during the study period that could not be controlled. Because the other serum parameters, except SUA, were not the main objectives of the present study, we have not considered exclusion criteria for agents lowering these parameters, in order to keep the study's quality at an acceptable level. Future studies can focus on the association of other serum parameters with cardiovascular mortality in HD patients in order to achieve more accurate results.
Considering the occurrence of different types of CVD during two years of follow-up in HD patients, the results showed that SUA significantly predicted cerebrovascular diseases $(\mathrm{OR}=0.6)$. The significantly lower incidence of cerebrovascular diseases in the third tertile (8.5\%), compared to the first (30.6\%) and second $(41.2 \%)$ tertile, as well as lower mean SUA values in patients with compared to without cerebrovascular diseases confirmed this association. However, other CVDs, including peripheral artery disease, AMI, unstable angina, and need to angiography, were not associated with SUA levels. Notably, most studies in this regard have focused on cardiovascular mortality and only few have reported incidence of CVD in HD patients and its association with SUA. In the study by Latif et al. SUA was categorized at the cut-off level of $8 \mathrm{mg} / \mathrm{dl}$ and the results showed that the prevalence of cerebrovascular diseases was higher in HD patients with SUA level of $\leq 8 \mathrm{mg} / \mathrm{dl}$ [10], which confirm the results of the present study; although the cut-off value and inclusion criteria of the patients differed. In general population, high SUA levels is considered a predictor of good clinical outcomes in patients with cerebrovascular diseases, associated to the antioxidative properties of uric acid [27, 28]. However, more studies are required in this regard to determine the mechanism of this association in HD patients.

One of the limitations of the present study was the effect of different factors on the study outcomes, some of which were controlled by setting different inclusion and exclusion criteria. However, some other confounders, such as the variability in serum levels of the studied parameters and variable renal status during the study period can affect the results of the studies.

\section{CONCLUSION}

The results of this study showed that CVD is common in HD patients and SUA level can predict two-year incidence of cerebrovascular diseases. However, other CVDs, including peripheral artery disease, acute myocardial infarction and unstable angina, were not associated with SUA levels. Furthermore, SUA and other serum parameters did not show significant predictive effect on two-year cardiovascular mortality. More studies are required to determine the predictive value of SUA on these parameters. 
Introducere: Hiperuricemia este asociată cu un risc mai mare pentru boală cerebrovasculară (CVD). La pacienții hemodializați (HD) nivelurile scăzute ale acidului uric (SUA) se asociază cu mortalitatea. Scopul studiului a fost de a evalua valoarea predictivă a SUA pentru CVD la pacienții cu HD.

Metode: Au fost urmăriți 205 pacienți HD între martie 2017 și 2020. S-au inregistrat date demografice, comorbidități și teste de laborator.

Rezultate: 130 de pacienți au fost eligibili, 62,9\% au fost bărbați, vârsta medie a fost de $59 \pm 13$ ani. 43,2\% dintre pacienți au avut boală arerială coronariană, 26,5\% au avut boală periferică arterială și 20,5\% CVD. SUA a fost $\leq 5,4 \mathrm{mg} / \mathrm{dL}$ la 52 de pacienți, 5,5-6,1 $\mathrm{mg} / \mathrm{dL}$ la 19 și $\geq 6,2 \mathrm{mg} / \mathrm{dL}$ la 59 de pacienți. Pacienții cu CVD au avut SUA mai mici $(p=0,006)$. Regresia logistică a demonstrat efectul independent al SUA asupra CVD $(p=0,008)$.

Concluzii: Nivelurile scăzute SUA au prezis CVD la pacienții cu HD, însă nu s-a observat un efect asupra afectării coronariene, bolii arteriale periferice și mortalității cardiovasculare.

Correspondence to: Dr. Toktam Alirezaei, M.D, Clinical Research development unit of Shohada Tajrish Hospital, Shahid Beheshti University of Medical science, Tehran Iran. Postal Code: 1989934148, alirezae.toktam@ sbmu.ac.ir

Tel: +982122718001

Fax: +982122718001

Acknowledgements: The authors of the present study sincerely thank all the shohada tajrish hospital's staff, who cooperated in this study, especially Hemodialysis staff.

Conflict of interest disclosure: The authors declare that there are not conflicts of interest.

\section{REFERENCES}

1. JHA V, GARCIA-GARCIA G, ISEKI K, LI Z, NAICKER S, PLATTNER B, et al. Chronic kidney disease: global dimension and perspectives. The Lancet. 2013;382(9888):260-72.

2. CLARKSON KA, ROBINSON K. Life on dialysis: a lived experience. Nephrol Nurs J. 2010;37(1):29-35.

3. CHUASUWAN A, POORIPUSSARAKUL S, THAKKINSTIAN A, INGSATHIT A, PATTANAPRATEEP O. Comparisons of quality of life between patients underwent peritoneal dialysis and hemodialysis: a systematic review and meta-analysis. Health Qual. life outcomes. 2020;18(1):1-11.

4. MOUSAVI SSB, SOLEIMANI A, MOUSAVI MB. Epidemiology of end-stage renal disease in Iran: a review article. Saudi J Kidney Dis Transpl. 2014;25(3):697-702.

5. BELADI-MOUSAVI SS, ALEMZADEH-ANSARI MJ, ALEMZADEH-ANSARI MH, BELADI-MOUSAVI M. Long-term survival of patients with end-stage renal disease on maintenance hemodialysis: a multicenter study in Iran. Iran J Kidney Dis. 2012;6(6):452-56.

6. COZZOLINO M, MANGANO M, STUCCHI A, CICERI P, CONTE F, GALASSI A. Cardiovascular disease in dialysis patients. Nephrol. Dial. Transplant. 2018;33(suppl_3): iii28-iii34.

7. COUSER WG, REMUZZI G, MENDIS S, TONELLI M. The contribution of chronic kidney disease to the global burden of major no communicable diseases. Kidney Int. 2011;80(12):1258-70.

8. OSSAREH S, FARROKHI F, ZEBARJADI M. Survival of Patients on Hemodialysis and Predictors of Mortality: a Single-Centre Analysis of Time-Dependent Factors. Iran J Kidney Dis. 2016;10(6):369-80.

9. SOLTANI Z, RASHEED K, KAPUSTA DR, REISIN E. Potential role of uric acid in metabolic syndrome, hypertension, kidney injury, and cardiovascular diseases: is it time for reappraisal? Curr. Hypertens. Rep. 2013;15(3):175-81.

10. LATIF W, KARABOYAS A, TONG L, WINCHESTER JF, ARRINGTON CJ, PISONI RL, et al. Uric acid levels and all-cause and cardiovascular mortality in the hemodialysis population. Clin J Am Soc Nephrol. 2011;6(10):2470-77.

11. KIM CS, JIN D-C, YUN YC, BAE EH, MA SK, KIM SW. Relationship between serum uric acid and mortality among hemodialysis patients: Retrospective analysis of Korean end-stage renal disease registry data. Kidney Res Clin Pract. 2017;36(4):368-76.

12. PARK C, OBI Y, STREJA E, RHEE CM, CATABAY CJ, VAZIRI ND, et al. Serum uric acid, protein intake and mortality in hemodialysis patients. Nephrol Dial Transplant. 2017;32(10):1750-57.

13. BEBERASHVILI I, ERLICH A, AZAR A, SINUANI I, FELDMAN L, GORELIK O, et al. Longitudinal study of serum uric acid, nutritional status, and mortality in maintenance hemodialysis patients. Clin J Am Soc Nephrol. 2016;11(6):1015-23.

14. LOVRE D, SHAH S, SIHOTA A, FONSECA VA. Managing diabetes and cardiovascular risk in chronic kidney disease patients. Endocrinol Metab Clin. 2018;47(1):237-57.

15. MURRAY T, GOLDBERG M. Chronic interstitial nephritis: etiologic factors. Ann Intern Med. 1975;82(4):453-55.

16. BEBERASHVILI I, SINUANI I, AZAR A, SHAPIRO G, FELDMAN L, STAV K, et al. Serum uric acid as a clinically useful nutritional marker and predictor of outcome in maintenance hemodialysis patients. Nutr J. 2015;31(1):138-47. 
17. FIRTH D. Bias Reduction of Maximum Likelihood Estimates. Biometrika 1993; 80(1):27-38.

18. HEINZE G, PLONER M, DUNKLER D, SOUTHWORTH H, HEINZE MG. “Package 'logistf” (2020).

19. KUCIRKA LM, GRAMS ME, LESSLER J, HALL EC, JAMES N, MASSIE AB, et al. Association of race and age with survival among patients undergoing dialysis. JAMA. 2011;306(6):620-26.

20. CHANDRASHEKAR A, RAMAKRISHNAN S, RANGARAJAN D. Survival analysis of patients on maintenance hemodialysis. Indian J Nephrol. 2014;24(4):206-13.

21. ECKARDT K-U, KIM J, KRONENBERG F, ALJAMA P, ANKER SD, CANAUD B, et al. Hemoglobin variability does not predict mortality in European hemodialysis patients. J Am Soc Nephrol. 2010;21(10):1765-75.

22. GOODKIN DA, FULLER DS, ROBINSON BM, COMBE C, FLUCK R, MENDELSSOHN D, et al. Naturally occurring higher hemoglobin concentration does not increase mortality among hemodialysis patients. J Am Soc Nephrol. 2011;22(2):358-65.

23. KREDIET RT, BALAFA O. Cardiovascular risk in the peritoneal dialysis patient. Nat Rev Nephrol. 2010;6(8):451-60.

24. CHANG TI, STREJA E, SOOHOO M, KIM TW, RHEE CM, KOVESDY CP, et al. Association of serum triglyceride to HDL cholesterol ratio with all-cause and cardiovascular mortality in incident hemodialysis patients. Clin $\mathrm{J}$ Am Soc Nephrol. 2017;12(4):591-602.

25. RAJU D, LALITHA D, KIRANMAYI P. A study of lipid profile and lipid peroxidation in chronic kidney disease with special reference to hemodialysis. J Clinic Res Bioeth. 2013;4(1):1-5.

26. MIKOLASEVIC I, ŽUTELIJA M, MAVRINAC V, ORLIC L. Dyslipidemia in patients with chronic kidney disease: etiology and management. Int J Nephrol Renovasc dis. 2017; 10:35-45.

27. ZHANG B, GAO C, YANG N, ZHANG W, SONG X, YIN J, et al. Is elevated SUA associated with a worse outcome in young Chinese patients with acute cerebral ischemic stroke? BMC Neurol. 2010;10(1):1-6.

28. CHIQUETE E, RUIZ-SANDOVAL JL, MURILLO-BONILLA LM, ARAUZ A, OROZCO-VALERA DR, OCHOA-GUZMÁN A, et al. Serum uric acid and outcome after acute ischemic stroke: PREMIER study. Cerebrovasc Dis. 2013;35(2):168-74.

Received 31 ${ }^{\text {st }}$ October 2021 